\title{
EVIDENCE OF BRASILIANO/PANAFRICAN DEFORMATION IN THE ARAGUAIA BELT: IMPLICATION FOR GONDWANA EVOLUTION
}

\author{
CANDIDO A.V. MOURA* \& HENRI E. GAUDETTE**
}

\begin{abstract}
RESUMO EVIDÊNCIA DE DEFORMAÇÃO BRASILIANA/PANAFRICANA NO CINTURÃ ARAGUAIA: IMPLICAÇÕES PARA A EVOLUÇÃOO DO GONDWANA. Datações de monocristais de zircão em granitos e veios graníticos sin a tardi-tectônicos, associados as rochas supracrustais do Cinturão Araguaia, por evaporacão gradativa de $\mathrm{Pb}$ forneceram idades platô para a razão ${ }^{207} \mathrm{~Pb}{ }^{206} \mathrm{~Pb}$ de $635 \pm 53 \mathrm{Ma}, 513 \pm 17 \mathrm{Ma}$ e de evaporaça gradativa de $\mathrm{Pb}$ forneceram idades plato pará a razão
$655 \pm 24 \mathrm{Ma}$. As idades destes cristais calculadas através da média ponderada dos diversos blocos de leitura da razão ${ }^{20} \mathrm{~Pb} /{ }^{206} \mathrm{~Pb}$ foram de $542 \pm 72 \mathrm{Ma}, 498 \pm 19 \mathrm{Ma}$ and $583 \pm 39 \mathrm{Ma}$. Considerando o carácter sin-tectônico, ou no máximo tardi-tectônico destas rochas graníticas, esses dados sugerem que o Ciclo Brasiliano foi responsável pela estruturacão do Cinturão Araguaia. Consequentemente, o desenvolvimento estrutural do Cinturão Araguaia pode ser colocado no contexto da amalgamação do Gondwana durante o Proterozóico Superior.
\end{abstract}

Palavras-chaves: Geocronologia, datação de monocristais de zircão, Cinturão Araguaia, Brasiliano/Pan-Africano, Gondwana.

\begin{abstract}
Single zircon Pb-evaporation dating of syntectonic to late-tectonic granitic ${ }_{20}$ veins and rocks, associated with the supracrustal rocks of the Araguaia belt-Brazil, gave plateau ages for the ${ }^{207} \mathrm{~Pb} /{ }^{206} \mathrm{~Pb}$ ratio of $635 \pm 53 \mathrm{Ma}, 513 \pm 24 \mathrm{Ma}$ and $655 \pm 24 \mathrm{Ma}$. The ${ }^{20} \mathrm{~Pb}^{206} \mathrm{~Pb}$ weighted average ages calculated for these zircons were $542 \pm 72 \mathrm{Ma}, 498 \pm 19 \mathrm{Ma}$ and $583 \pm 39 \mathrm{Ma}$. Considering the suggested syntectonic, or at most, late-tectonic emplacement for these igneous rocks, these ages suggest that the Brasiliano thermo-tectonic cycle was responsible for the structural evolution of the Araguaia Belt. Consequently, the structural evolution of the Araguaia belt may be interpreted as a result of the Late Proterozoic assemblage of the Gondwana supercontinent.
\end{abstract}

Keywords: Geochronology, Single Zircon Dating, Araguaia Belt, Brasiliano/Pan African, Gondwana.

INTRODUCTION The Paraguay-Araguaia belt in north-central Brazil is an important suture zone which divides the South American Platform into two distinct geotectonic domains: (1) a Pre-Brasiliano Domain where there is no record of the Brasiliano/Pan-African orogeny, and (2) the Brasiliano Domain where the Brasiliano tectonomagmatic cycle has reworked Archean and Early to Middle Proterozoic rocks, leading to the generation of several Late Proterozoic belts (Brito Neves \& Cordani 1991). However, debate about the timing of structural development of the Araguaia Belt, which is the northern segment of the Paraguay-Araguaia Belt, has occurred for the last two decades.

Some investigations have suggested a Brasiliano (900$500 \mathrm{Ma}$ ) age for the structural development of this belt (Hasui et al. 1977, Souza 1984, Teixeira 1984, Santos et al. 1984, Abreu 1990). In contrast, thermo-tectonic events related to the Uruac,uano orogeny $(1.4-1.0 \mathrm{Ga}$.) have been proposed as the major tectonism responsible for the deformation and metamorphism of the Araguaia Belt by Hasui et al. (1980), Hasui et al. (1984a) and Herz et al. (1989). The Trans-Amazonian orogeny $(2.2-1.9 \mathrm{Ga})$, recognized in a large part of Brazil, has also been considered by Cunha et al. (1981) to play an important role in the formation of the Araguaia Belt. Recent structural interpretations which consider the Araguaia Belt as the product of a regional low angle ductile shear event related to the overthrusting of the Brasilia block (in the east) on the Araguacema block (to the west), have suggested an Early Proterozoic or perhaps even an Archean age for this tectonic event (Hasui et al. 1988, Hasui \& Costa 1990). Determination of the timing of structural development of the Araguaia Belt is fundamental to an understanding of the assemblage of West Gondwana, and the role that the Araguaia Belt has played in the evolution of this Late Proterozoic mega-continent.

In the southeastern part of the Araguaia Belt, near the city of Paraíso do Tocantins, granitic rocks and veins associated with the supracrustal sequences of this belt occur. Since these granitic rocks and veins are suggested to have been emplaced during the deformational and metamorphic episodes that led to the development of the Araguaia Belt (Hasui \& Costa 1990), their age offers the possibility of investigating the timing of the structural development of this belt. The single zircon $\mathrm{Pb}$-evaporation technique (Kober 1986, Olszewski et al. 1990) was used to date these rocks, which are associated with the supracrustal sequences of the Araguaia Belt, in order to establish the time of deformation and metamorphism of the Araguaia Belt.

GEOLOGY The Araguaia Belt is located at the northern part of the Tocantins Structural Province (Almeida et al. 1981) and corresponds to the northern portion of ParaguayAraguaia fold belt defined by Almeida et al. (1976). The Araguaia Belt is $1.200 \mathrm{~km}$ long and more than $100 \mathrm{~km}$ wide, and has a north-south orientation (Fig. 1). On the west side, it is bordered by the Amazonian Craton and is partially covered by Quaternary sediments. In the north, northeast and east, the belt is covered by Phanerozoic sediments of the Parnafba Basin. In the south and southeast, the Araguaia Belt is bordered by the granulitic rocks of the Porto Nacional Complex (Fig. 1). These granulitic rocks have been interpreted as marking a suture zone representing the base of a crustal block that overthrust the basement and supracrustal rocks of the Araguaia Belt (Costa et al. 1988b, Hasui \& Costa 1990). The overthrust block is known as the Brasília block, and lies on the east side of the

\footnotetext{
* Laboratório de Geologia Isotópica, Departamento de Geoquímica e Petrologia, Centro de Geociências, Universidade Federal do Pará, Caixa Postal 1611, CEP 66075-000, Belém, Pará Brasil, FAX (091) 229-9677

** Department of Earth Sciences, University of New Hampshire. 03824, Durham, New Hampshire, USA, FAX (603) 862-1915
} 
presumed suture zone. The overthrusted block, named Araguacema block, lies to the west of the granulite belt and has been interpreted as part of the Amazonian Craton (Hasui \& Haralyi 1985, Costa 1985).

The Araguaia Belt is composed of a metamorphosed psammitic and pelitic sequence with minor contributions of chemical sediments and mafic and ultramafic rocks. Both the metamorphic grade and deformation of these rocks increase from west to the east. The vergence of the structures within the Araguaia Belt is to the west and in the direction of the Amazonian Craton. Dome structures which are aligned in a N-S direction are associated with the highest grade metamorphic rocks. These structures define doubly plunging anticlines, the cores of which contain gneissic rocks interpreted as the basement rocks of this belt.

Geologic studies in this belt, mainly during the last fifteen years, have developed a lithostratigraphic framework (see figures 1 and 2). The basement rocks have been separated into the Colmeia Complex (Costa 1980), Rio dos Mangues Complex, Rio do Coco Group, Serrote Granite and Matança Granite (Costa et al 1983, Hasui et al. 1984b) and the Cantão Gneiss (Souza 1984 and Souza et al. 1985). The supracrustal sequences were combined into the Estrondo and Tocantins Groups (Abreu 1978), and the Tucurui Group (Matta 1982). The first two groups were named Baixo Araguaia Supergroup by Abreu (1978). Metamorphosed ultramafic bodies intercalated in the Estrondo and Tocantins Groups and also in the basement rocks were included in this Supergroup (Dall'Agnol el al. 1986). Granitic rocks associated with the supracrustal sequences of this belt (Costa et al. 1983, Santos et al. 1984, Hasui et al. 1984b, Bulhões \& Dall'Agnol 1985) and sedimentary rocks of Rio das Barreiras Formation (Hasui et al. 1977) complete the lithostratigraphic units of the Araguaia Belt.

The granitic rocks associated with the supracrustal sequences of the Araguaia Belt, in general are small, rounded to elliptical granitic stocks, emplaced in the rocks of the Estrondo Group. They are not represented in the figure 1 due to scale limitations. The largest of these bodies is the Santa Luzia Granite which crops out in the southeastern segment of the Araguaia Belt, near the city of Paraíso do Tocantins (Fig. 2). The Santa Luzia Granite, made up of granite and granodiorite, is massive in the center but foliated at its edges. Xenoliths of the country rocks (schists) are present and the country rock has been invaded by both concordant and discordant aplitic and pegmatitic veins (Costa et al 1983, Hasui et al. 1984b). The emplacement of the Santa Luzia Granite has been interpreted by Hasui \& Costa (1990) as contemporaneous with the regional low angle ductile shear event that led to the formation of the Araguaia Belt.

In the study area, granitic veins up to $30 \mathrm{~cm}$ thick are emplaced concordantly with the trend of foliation of the gneissic rocks of the Canto da Vazante Formation, which is part of the Estrondo Group (Fig. 2). In this area, some of these veins are folded or stretched showing pinch and swell structures. These structures constitute independent evidence that emplacement of the veins was accompanied by deformation. As most of these granitic veins are concordant with the general N-S trend of the Araguaia Belt, it is assumed that they were emplaced at the time of the structural development of this belt.

METHODOLOGY Since the pioneer work of Kober (1986), increase in the use of the single zircon Pb-evaporation technique in the dating of zircon in different laboratories in the world has occurred (for example, Kroner \& Todd 1988, Olszewski et al. 1990, Ansdell \& Kyser 1991, Cocherie et al. 1992). The increasing number of studies using this technique is due to the fact that one can analyze a single zircon grain without any previous chemical treatment. As a result, a very low laboratory $\mathrm{Pb}$ blank, required to perform isotope analyses of single zircon grains by the conventional U-Pb chemical techniques, is not necessary or required by the $\mathrm{Pb}$-evaporation technique (Kober 1986, 1987).

The single zircon $\mathrm{Pb}$-evaporation technique determines the ${ }^{207} \mathrm{~Pb} /{ }^{208} \mathrm{~Pb}$ age of a zircon grain by stepwise heating of the filament in a solid source thermal ionization mass spectrometer. The principle behind this technique is that U$\mathrm{Pb}$ evolution in the crystalline domains of the zircon would have closed system behaviour. As a result, the ${ }^{207} \mathrm{~Pb} /{ }^{206} \mathrm{~Pb}$ ratio of the crystalline domains would present a concordant age. In contrast, $\mathrm{U}-\mathrm{Pb}$ fractionation, which is responsible for the discordant character of the zircon grain, would occur in the non-crystalline domains of the zircon crystal such as the metamict portions, mineral intergrowths, fractures, and rims (Kober 1986, 1987). Since the $\mathrm{Pb}$ in the crystalline domains is situated in the most retentive sites of the crystal, it evaporates at higher temperatures than the $\mathrm{Pb}$ in the noncrystalline domains of the grain (Kober 1986).

In this work, the ages of granitic veins and the Santa Luzia Granite associated with the supracrustal rocks of the Araguaia Belt were investigated using a single Re-filament $\mathrm{Pb}$-evaporation technique (Olszewski et al. 1990), instead of a double filament as originally introduced by Kober $(1986,1987)$. The zircon crystal is deposited in a canoeshaped Re-filament and the temperature of the filament is increased in several steps so that the $\mathrm{Pb}$ present in the different parts of the crystal is evaporated at a different temperature (and time). The evaporated $\mathrm{Pb}$ is immediately ionized once the evaporation temperature reaches the $\mathrm{Pb}$ ionization temperature. A block of ten ${ }^{207} \mathrm{~Pb} /{ }^{206} \mathrm{~Pb}$ ratios is determined for each $\mathrm{Pb}$-evaporation step. The average ${ }^{207} \mathrm{~Pb} /{ }^{206} \mathrm{~Pb}$ ratio of each block of data is plotted in a binary diagram against the respective block number which in fact represents the different heating steps. The ${ }^{207} \mathrm{~Pb} /{ }^{206} \mathrm{~Pb}$ ratios of data reach a maximum value and define a plateau during the stepwise heating, since the $\mathrm{Pb}$ evaporated at higher temperatures is that located in the most retentive part of the crystal structure. This plateau age is the ${ }^{207} \mathrm{~Pb} /{ }^{200} \mathrm{~Pb}$ age of the dated zircon grain and is considered to be a concordant age (Kober 1986, 1987, Ansdell \& Kyser 1991).

The single filament mass spectrometer analysis for single zircon grain $\mathrm{Pb}$-evaporation was developed at the Laboratory of Mass-Spectrometry of the University of New Hampshire (LMS/UNH) using a secondary electron multiplier as the collector system. Calibration of the single zircon $\mathrm{Pb}$ evaporation technique using a single filament was done for this study by using zircons from a Middle Proterozoic biotite granite from the Amazonian region of Brazil. Zircons from this granite were previously analyzed by dr. W. Olszewski at LMS/UNH using the conventional U-Pb isotope techniques. These results were only slightly discordant and gave a Concordia upper intercept age of $1.518 \pm 25 \mathrm{Ma}$ (1s). Two individual zircon crystals from the same sample were analyzed for this study by the $\mathrm{Pb}$-evaporation technique. The ${ }^{207} \mathrm{~Pb} /{ }^{206} \mathrm{~Pb}$ ages obtained were $1.498 \pm 48 \mathrm{Ma}$ and $1.522 \pm 50 \mathrm{Ma}(2 \mathrm{~s})$, with a weighted average age of $1.510 \pm$ $17 \mathrm{Ma}$. These ages agree, within the limits of errors, with the age obtained using the conventional U-Pb technique.

The actual temperature of the $\mathrm{Pb}$-evaporation analyses are not recorded since it is not possible to directly measure the temperature of the filament at LMS/UNH. The filament current during the $\mathrm{Pb}$-evaporation/ionization process generally ranged between 2.2 Amps (beginning of the analysis) and 2.6 Amps (end of the analysis).

A $30 \mathrm{~cm}$ thick granitic vein and the Santa Luzia Granite were sampled for single zircon $\mathrm{Pb}$-evaporation dating. The 

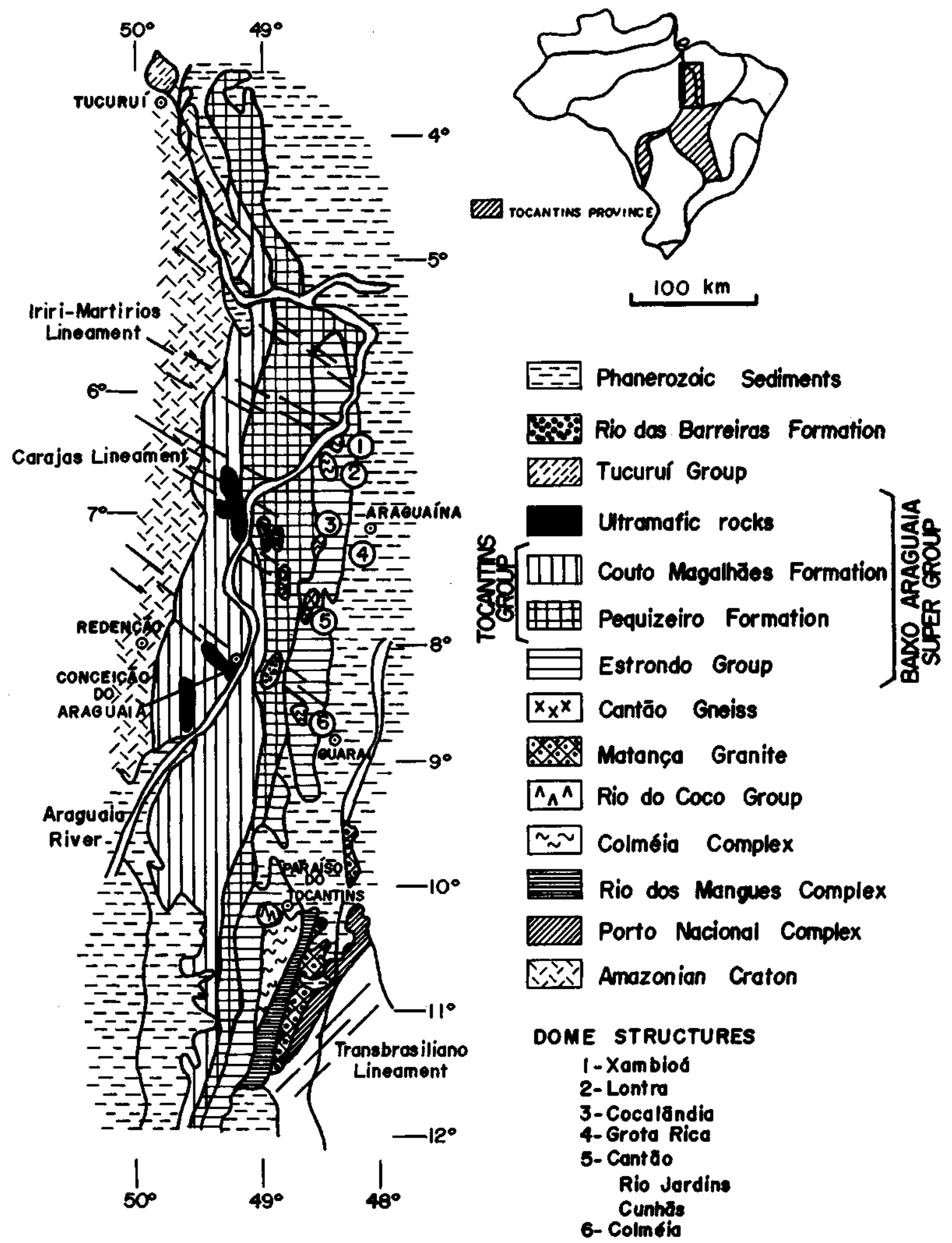

Figure 1-Simplified geologic map of the Araguaia Belt after Costa et al. (1988a) and Dall'Agnol et al. (1988) Figura 1- Mapa Geologico simplificado do Cinturão Araguaia segundo Costa et al. (1988a) e Dall'Agnol et al. (1988)

sample site is approximately $30 \mathrm{~km}$ northeast of the city of Parai'so do Tocantins (Fig. 2). The zircons were separated from 40 to $50 \mathrm{~kg}$ of samples using the standard techniques based on their density, magnetic susceptibility and size. Zircon grains from the $0^{\circ}$ non-magnetic, $>140$ mesh fraction, were used for the $\mathrm{Pb}$-evaporation analyses.
Zircon populations from both the vein and the granitic rock are very similar. The zircons are translucent and generally stubby euhedral to subhedral crystals, although a few prismatic crystals $(3: 1)$ may be present. Under the binocular microscope, their color is pink to pinkish-brown. In general, the zircons are intensely fractured and contain 



(3) Sampl vite

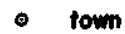

roods

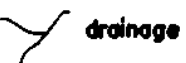

figure 2 - Simplified geologic map of the Paraíso do Tocantins region after Costa et al. (1983) and Costa et al. (1988a). Samples sites are: "a" granitic vein and " $b$ " Santa Luzia Granite

Figura 2 - Mapa geológico simplificado da região de Paraíso do Tocantins, segundo Costa et al. (1983) e Costa et al. (1988a). Sítios amostrados para os veios graníticos e para o Granito Santa Luzia são indicados com as letras "a" e "b" respectivamente

black inclusions. Observations with the polarized light microscope show the presence of possible relict cores in some grains. Zoned crystals are also common.

RESULTS The precise measurement of the ratio in young zircons is not an easy task. Due to the exponential decay of $\mathrm{U}$ to $\mathrm{Pb}$, the ${ }^{207} \mathrm{~Pb} /{ }^{206} \mathrm{~Pb}$ ratio increases faster in old zircons than in young zircon crystals. A variation of one unit in the third decimal place for example, produces a variation of $40 \mathrm{Ma}$ in the ${ }^{207} \mathrm{~Pb} /{ }^{206} \mathrm{~Pb}$ age of a zircon $400 \mathrm{Ma}$ old, and $10 \mathrm{Ma}$ in a zircon $2.500 \mathrm{Ma}$ old. Consequently, in order to obtain a precise determination of the ${ }^{207} \mathrm{~Pb} /{ }^{206} \mathrm{~Pb}$ age of zircons of Upper Precambrian or Paleozoic age, the error associated with the ${ }^{207} \mathrm{~Pb} /{ }^{206} \mathrm{~Pb}$ ratio determination of each block of data has to be less than five in the fourth decimal place. However, the error associated with ${ }^{207} \mathrm{~Pb} /{ }^{206} \mathrm{~Pb}$ ratio determination using single filament procedures is usually greater than one in the third decimal place. Although this is not critical to Archean and Lower Proterozoic zircon age determinations, it places some limitations in the interpretation of ${ }^{207} \mathrm{~Pb} /{ }^{206} \mathrm{~Pb}$ ages of young zircons due to the significant variations that may be obtained in these ages. In general, variations in the ${ }^{207} \mathrm{~Pb} /{ }^{206} \mathrm{~Pb}$ ratio make it difficult in some cases to clearly define a plateau age.

In order to minimize this problem, two approaches were used in this study to calculate the age of the sampled granitic vein and rock. In the first method, the best plateau age was defined by eliminating those scattered blocks of data based on a visual evaluation of the ${ }^{201} \mathrm{~Pb} /{ }^{206} \mathrm{~Pb}$ ratios plotted in the single zircon diagram. This approach is very subjective but it is useful since any or all data would perhaps be eliminated statistically. The second approach calculates the weighted average ${ }^{207} \mathrm{~Pb} /{ }^{206} \mathrm{~Pb}$ ratio without eliminating any block of data. In this case, the ${ }^{207} \mathrm{~Pb} /{ }^{206} \mathrm{~Pb}$ age is a weighted average age. This procedure is particularly preferred since it weighs the errors associated in each block of data, and is statistically more consistent. The ${ }^{207} \mathrm{~Pb} /{ }^{206} \mathrm{~Pb}$ weighted ratios are calculated using the equation:

$$
\mathrm{T} \pm \mathrm{W}=\left(\sum_{\mathrm{i}=1}^{\mathrm{n}} \mathrm{T}_{\mathrm{i}} \mathrm{W}_{\mathrm{i}}\right) /\left(\sum_{\mathrm{i}=1}^{\mathrm{n}} \mathrm{W}_{\mathrm{i}}\right) \pm\left(1 / \sum_{\mathrm{i}=1}^{\mathrm{n}} \mathrm{W}_{\mathrm{i}}\right)^{-2}
$$

where $\mathrm{T}$ is the ${ }^{207} \mathrm{~Pb} /{ }^{206} \mathrm{~Pb}, \mathrm{w}$ is the standard error at $2 \mathrm{~s}$ and $\mathrm{W}_{\mathrm{i}}=1 / \mathrm{w}_{\mathrm{i}}^{2}$

All the zircon crystals analyzed were fractured, as grains suitable for $\mathrm{Pb}$-evaporation analyses in both vein and granitic rock all contained fractures. A number of grains of the granitic vein and rock were analyzed, however, only a few grains gave a significant number of blocks of ${ }^{207} \mathrm{~Pb} /{ }^{206} \mathrm{~Pb}$ ratios that would allow a valid interpretation. These results are displayed in table 1 and in figure 3 .

The weighted average age for the two zircons from the granitic vein are $542 \pm 72 \mathrm{Ma}$ and $498 \pm 19 \mathrm{Ma}$ (Tab. 1 and Fig. 3). Zircon from the Santa Luzia Granite has a weighted average age of $583 \pm 39 \mathrm{Ma}$. The plateau ages obtained by visual elimination of apparently spurious values of ${ }^{207} \mathrm{~Pb} /$ ${ }^{206} \mathrm{~Pb}$ ratios are $635 \pm 53 \mathrm{Ma}$ and $513 \pm 17 \mathrm{Ma}$ for zircon grains from the granitic vein and $655 \pm 24 \mathrm{Ma}$ for the zircon of the Santa Luzia Granite (Tab. 1 and Fig. 3). The plateau ages are older than the weighted average age. In the case of the Santa Luzia Granite, the plateau age agrees within the limits of the error with a Rb-Sr whole rock age of $665 \pm 12$ $\mathrm{Ma}(1 \mathrm{~s})$ recently determined for this granitic rock (J.M. Lafon, written communication).

DISCUSSION The limitations in the measurements of such low ${ }^{207} \mathrm{~Pb} /{ }^{206} \mathrm{~Pb}$ ratios (see Tab. 1) make the $\mathrm{Pb}$-evaporation data difficult to interpret. The difference in the ages 

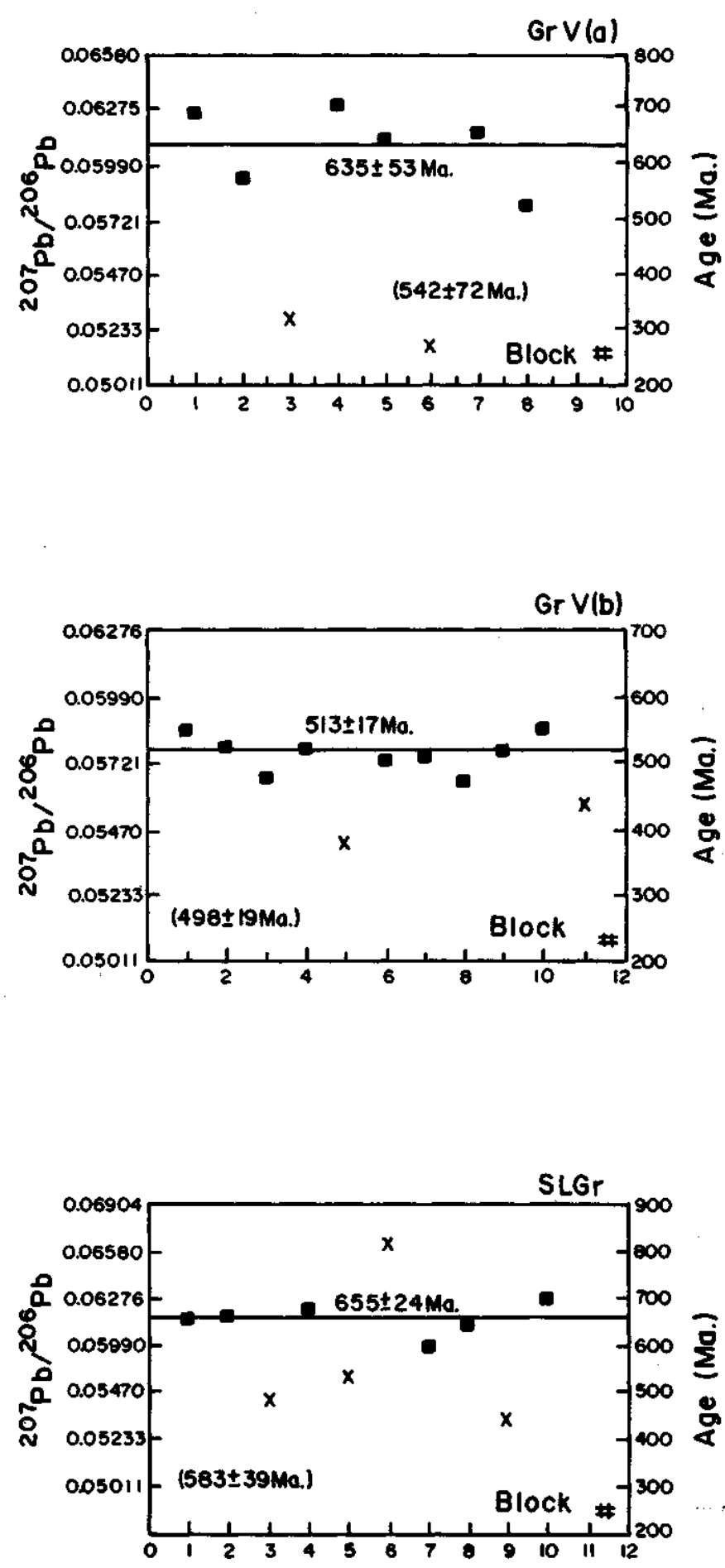

Figure 3 - Single zircon diagram for the granitic vein $[G r V(a)$ and GrV(b)] and Santa Luzia Granite (SLGr) associated with the supracrustal rocks of the Araguaia Belt. Number between parentheses is the age of the zircon calculated using the weighted average ${ }^{209} \mathrm{~Pb}{ }^{206} \mathrm{~Pb}$ ratio. Ratios eliminated from the calculation of the average plateau age are those plotted in " $x$ "

Figura 3 - Diagrama de monocristais de zircão para os veios graníticos [GrV(a) and GrV(b)] e Granito Santa Luzia (SLGr) associados as sequências supracrustais do Cinturão Araguaia. Números entre parênteses representam idades calculadas a partir da media ponderada das razões ${ }^{207} \mathrm{~Pb} /{ }^{106} \mathrm{~Pb}$. As razões eliminadas do cálculo da idade platô média são aquelas representadas por " $\mathrm{x}$ " obtained by the two different methods of calculation in this study suggests that the weighted average ages represent the minimum age of crystallization of the zircons. Consequently, as suggested by the Rb-Sr whole rock data for the Santa Luzia Granite, an age of about 650 Ma may be assigned to these rocks. In spite of limitations in the definition of the precise age of the Santa Luzia Granite and granitic veins by the $\mathrm{Pb}$-evaporation technique, our results indicate that the emplacement of these rocks occurred during the Brasiliano thermo-tectonic cycle.

The impact of the Brasiliano cycle in the Araguaia belt has been recorded in the K-Ar ages of muscovite, biotite and hornblende of the basement and supracrustal rocks of the Araguaia Belt (Hasui et al. 1980, Macambira 1983). This thermo-tectonic event is also recorded in the $\mathrm{Rb}-\mathrm{Sr}$ mineral ages of the basement gneisses of the Araguaia Belt (Lafon et al. 1990, Moura 1992). The definition of a Brasiliano age by three different isotopic systems suggests that this tectonometamorphic event was responsible for the structural evolution of the Araguaia Belt. Those interpretations which relate the formation of the Araguaia Belt to older tectono-metamorphic cycles (Uruaçuano and Trans-Amazonian) are opposed by the ${ }^{207} \mathrm{~Pb} /{ }^{206} \mathrm{~Pb}$ zircon ages presented here.

As a consequence of the Brasiliano age of the zircon from granitic veins and Santa Luzia Granite, a careful re-evaluation of the hypothesis of Costa et al. (1988a) and Hasui \& Costa (1990) concerning the evolution of the Araguaia Belt is warranted. They proposed the structural development of this belt as a result of the oblique collision between the Brasília and the Araguacema crustal blocks. This continentcontinent collision is suggested to be older than $1.873 \pm 25$ $\mathrm{Ma}$, which is the age of the undeformed granitic rocks of the Lajeado Suite intrusive into the Archean gneisses of the overthrust Brasília block (Costa et al. 1988a). The granites of the Lajeado Suite crop out principally 10-15 km east of the Porto Nacional Complex. One small body of this suite (not shown in figure 1 due to scale limitations) intrudes the Porto Nacional Complex.

If this proposed continent-continent collision model for the Araguaia Belt is accepted, the single zircon ages of the Santa Luzia Granite and granitic vein of this study indicate a Brasiliano age for this event. In this case, conclusions based on the established stratigraphic relationship between the granitic rocks of the Lajeado Suite and the gneissic rocks of the Brasília Block cannot be extrapolated to the gneissic rocks of the Araguacema Block.

The sole Lower to Middle Proterozoic granitic rock thus far recognized in the Araguaia Belt is the Cantão Gneiss (Souza et al. 1985), which is interpreted as a basement inlier of the Araguaia Belt (Fig. 1). The Cantão Gneiss is an orthogneiss with unique augen structure whose $\mathrm{Rb}-\mathrm{Sr}$ whole rock age of $1.774 \pm 31 \mathrm{Ma}$ (Souza 1984, Lafon et al. 1990) agrees with the single zircon age of $1.846 \pm 64 \mathrm{Ma}(2 \mathrm{~s})$ obtained by Moura (1992). Thus, the agreement between these two ages strongly suggests a Lower to Middle Proterozoic emplacement for the igneous protolith of the Cantão Gneiss.

The correlation of the Cantão Gneiss with the granitic rocks of the Lajeado Suite been suggested by Abreu (1990). Although this correlation may be viewed as preliminary, the age of the Cantão Gneiss indicates that the Lower to Middle Proterozoic intrusive granites of the Araguacema block within the Araguaia Belt were affected by the thermo-tectonic event which developed this belt. This conclusion is supported by the mineral $\mathrm{Rb} / \mathrm{Sr}$ data (Lafon et al. 1990) which show ages ranging from 460 to $500 \mathrm{Ma}$ for the Cantão Gneiss.

In order for the single zircon ages of this study to be compatible with the stratigraphic, structural and geochronological data now available, the evolution of the Araguaia 
Table 1-Single zircon Pb-evaporation data for the Santa Luzia Granite (SLGr) and correlated granitic veins [GrV(a) and $G r V(b)]$. Uncertainties are the standard error at $2 \sigma$

Tabela 1 - Dados de monocristais de zircão do Granito Santa Luzia (SLGr) e veios graníticos [GrV(a) and GrV(b)] associados. Incertezas são reportadas pelo erro padrão em $2 \sigma$

\begin{tabular}{|c|c|c|c|c|c|c|c|c|c|}
\hline \multirow[b]{2}{*}{ Block\# } & \multicolumn{3}{|c|}{$\begin{array}{c}\operatorname{GrV}(\mathrm{a}) \\
\text { pink, translucent, stubby, fractured }\end{array}$} & \multicolumn{3}{|c|}{$\begin{array}{c}G r V(b) \\
\text { pink, translucent, stubby, fractured }\end{array}$} & \multicolumn{3}{|c|}{$\begin{array}{c}\text { SLGr } \\
\text { pink, translucent, stubby, fractured }\end{array}$} \\
\hline & ${ }^{207} \mathrm{~Pb} /{ }^{26} \mathrm{~Pb}$ & std. error & Age [Ma] & ${ }^{207} \mathrm{~Pb} /{ }^{206} \mathrm{~Pb}$ & std. error & Age [Ma] & ${ }^{207} \mathrm{~Pb} /{ }^{206} \mathrm{~Pb}$ & std. error & Age [Ma] \\
\hline 1 & 0.06255 & 0.00565 & 693 & 0.05853 & 0.00271 & 550 & 0.06148 & 0.00206 & 656 \\
\hline 2 & 0.05929 & 0.00271 & 575 & 0.05781 & 0.00177 & 523 & 0.06167 & 0.00510 & 663 \\
\hline 3 & $0.05287^{*}$ & 0.00469 & 323 & 0.05667 & 0.00151 & 479 & $0.05687^{*}$ & 0.00391 & 486 \\
\hline 4 & 0.06301 & 0.00872 & 709 & 0.05775 & 0.00170 & 520 & 0.06208 & 0.00671 & 677 \\
\hline 5 & 0.06122 & 0.01017 & 649 & $0.05452 *$ & 0.00146 & 380 & $0.05509^{*}$ & 0.00317 & 543 \\
\hline 6 & $0.05165^{*}$ & 0.00760 & 270 & 0.05733 & 0.00114 & 504 & $0.06641^{*}$ & 0.01288 & 819 \\
\hline 7 & 0.06160 & 0.01612 & 660 & 0.05740 & 0.00235 & 507 & 0.05988 & 0.00189 & 599 \\
\hline 8 & 0.05794 & 0.01886 & 525 & 0.05645 & 0.00152 & 470 & 0.06116 & 0.00951 & 645 \\
\hline 9 & & & & 0.05766 & 0.00373 & 517 & $0.05572 *$ & 0.00399 & 441 \\
\hline 10 & & & & 0.05849 & 0.00114 & 549 & & & \\
\hline 11 & & & & $0.05564 *$ & 0.00401 & 438 & & & \\
\hline W.A. & $0.05832 \pm 196$ & & $542 \pm 72$ & $0.05716 \pm 50$ & & $498 \pm 19$ & $0.05942 \pm 110$ & & $583 \pm 39$ \\
\hline Average & & & $635 \pm 53$ & & & $513 \pm 17$ & & & $655 \pm 24$ \\
\hline
\end{tabular}

Belt cannot be correlated with the pre-Brasiliano tectonometamorphic events that affected the gneissic rocks of the Brasília Block. Thus, the structural development of the Araguaia Belt may be interpreted as a result of the Late Proterozoic assemblage of the Gondwana supercontinent. Therefore, in this portion of Gondwana during the Late Proterozoic, deformation and metamorphism of supracrustal sequences, accompanied by the generation and emplacement of small granitic bodies occurred, in addition to the reworking of the Archean and Lower to Middle Proterozoic rocks.

CONCLUSIONS Single zircon Pb-evaporation ages of $635 \pm 53 \mathrm{Ma}(542 \pm 72 \mathrm{Ma})$ and $513 \pm 17 \mathrm{Ma} \mathrm{(498 \pm 19}$ $\mathrm{Ma})$ for zircon grains from the granitic vein and $655 \pm 24 \mathrm{Ma}$ $(583 \pm 39 \mathrm{Ma})$ for the zircon of the Santa Luzia Granite, are interpreted as minimum ages of crystallization of these rocks. Since the emplacement of these granitic rocks associated with the supracrustal rocks of the Araguaia Belt has been considered to be syntectonic to late-tectonic, the single zircon data suggest that the Brasíliano thermotectonic cycle was responsible for the structural evolution of the Araguaia Belt. The structural development of the Araguaia Belt may therefore be interpreted as a result of the Late Proterozoic assemblage of the Gondwana supercontinent.

Acknowledgements This work was conducted with the financial support of CAPES while C.A.V. Moura was a PhD student at University of New Hampshire. Discussions with F.A.M. Abreu and P.S.S. Gorayeb have helped to improve the manuscript.

\section{REFERENCES}

ABREU, F.A.M. 1978. Estratigrafia e Evolução Estrutural do Segmento Setentrional da Faixa de Dobramentos Paraguai-Araguaia. Belém. 90 p. (Dissertação de Mestrado, NCGG/UFPa).

ABREU, F.A.M. 1990. Evolução Geotectônica da Região Meio Norte do Brasil e sua Correlação com a África Ocidental. Belém. 440 p. (Tese de Doutorado, Centre de Geociências/UFPa).

ALMEIDA, F.F.M.; HASUI, Y; BRITO NEVES, B.B. 1976. The Upper Pre-Cambrian of South America. Bol. hist. Geoc. USP, 7:45-80.

ALMEIDA, F.F.M.; HASUI, Y.; BRITO NEVES, B.B.; FUCK, R. 1981. Brazilian structural provinces: an introduction.Earth Sci. Rev., 17:1-29.

ANSDELL, K.M. \& KYSER, T.K. 1991. Plutonism, deformation, and metamorphism in the Proterozoic Flin Flon greenstone belt, Canada: limits on timing provided by the single-zircon $\mathrm{Pb}$-evaporation technique. Geology, 19:518-521.

BRITO NEVES, B.B. \& CORDANI, U.G. 1991. Tectonic evolution of South America during the Late Proterozoic. Prec.Res, 53.23-40.

BULHOES, E.M. \& DALL'AGNOL, R. 1985. Mapeamento geologico e petrografia do Granodiorito Presidente Kennedy - Faixa de Dobramentos Araguaia (GO). In: SIMP. GEOL. AMAZÔNIA, 2. Belém, 1985. Anais... Belém, SBG/NO. v. 1, p. 59-76.
COCHERIE, A.; GUERROT, C.; ROSSI, Ph. 1992. Single-zircon dating by step-wise evaporation: Comparison with other geochronological techniques applied to the Hercynian granites of Corsica, France. Chem. Geol., 101:131-141. (Isotope Geoscience Section).

COSTA, J.B.S. 1980. Aspectos litoestruturais da região de Colméia - Goiás. Belém. 71 p. (Dissertação de Mestrado, NCGG/UFPa).

COSTA, J.B.S. 1985. Aspectos Litoestruturais e Evolução Crustal da Região Centro-Norte de Goiás. Belém. 209 p. (Tese de Doutorado, Centra de Geociências/UFPa).

COSTA, J.B.S.; GORAYEB, P.S.S.; BEMERGUY, R.L.; GAMA, T., Jr.; KOTSCHOUBEY, B.; LEMOS, R.L. mi.Projeto Paraíso do Norte. Belém. DNPM/UFPa. 125 p. (Relatório Final).

COSTA, J.B.S.; HASUI, Y.; GORAYEB, P.S.S. 1988a. Relações estruturais entre a Faixa Araguaia e o Maciço Goiano na região de Paraíso do Norte - Gurupi, GO. In: CONGR. BRAS. GEOL., 35. Belém, 1988. Anais... Belém, SBG. v. 5, p. 2187-2196.

COSTA, J.B.S.; HASUI, Y.; HARALIY, N.L.E. 1988b. A zonade articulacão dos blocos Brasília e Araguacema no centro-norte de Goiás. In: CONGR. BRAS. GEOL., 35. Belém, 1988. Anais... Belém, SBG. v. 5, p. 2197-2207. 
CUNHA, B.C.C.; POTIGUAR, L.A.T; IANHEZ, A.C.: BEZERRA, P.E.L; PITTHAN, J.H.L.; SOUZA, J.J.J.; MONTALVÃO, R.N.G.; SOUZA, A.M.S.; MILDRED, P.R.: TASSINARI, C.C.G. 1981. Geologia. In: PROJETO RADAMBRASIL. Levantamenlo de Recursos Naturais Folha SC-22 Tocantins. Rio de Janeiro, DNPM, MME v. 22, p. 21-196.

DALL'AGNOL, R.; GORAYEB, P.S.S.; TEIXEIRA, N.P.; SANTOS, M.D.; MACAMBIRA, J.B. \& KOTSCCHOUBEY, B. 1986. A faixa de dobramentos Araguaia. Contribuição para o Projeto Faixa Orogênica. Belém. $76 \mathrm{p}$.

DALLAGNOL R. TEIXEIRA NP. MACAMBIRA JB. KOTSCHOUBEY, B.; GORAYEB, P.S.S.; SANTOS, M.D. 1988. Petrologia dos gnaisses e micaxistos da porção norte da faixa de dobramentos Araguaia, Goiás-Brasil. In: CONGR. LATINO-AMER. GEOL. 7. Belém, 1988. Anais... Belém, SBG. v. 1, p. 1-19.

HASUI, Y. \& HARALYI N.L.E. 1985. A megaestruturação de Goiás. In: SIMP. GEOL. CENTRO-OESTE, 2. Goiânia, 1985 .Anais... Goiânia, SBG. p. 120-144.

HASUI, Y. \& COSTA, J.B.S. 1990.0 Cinturão Araguaia: urn novo enfoque estrutural-estratigrático. In: CONGR. BRAS. GEOL., 36. Natal, 1990. Anais.. Natal SBG. v. 5, p. 2535-2549.

HASUI, Y; ABREU, F.A.M.; RANGEL, J.M.R. 1977. Estratigrafia da Faixa de Dobramentos Paraguai Araguaia no centro-norte do Brasil. Bol. Inst.Geoc. LW., 8:107-118.

HASUI, Y; TASSINARI, C.C.G.; SIGA, O, Jr; TEIXEIRA, W ; ALMEIDA. F.F.M.; KAWASHITA, K. 1980. Dataçoes Rb-Sre K-Ardo centre norte do Brasil e seu significado geológico-geotectônico. In: CONGR. BRAS. GEOL., 31. Camboriu, 1980. Anais... Camboriú, SBG. v. 5, p. 2659-2667.

HASUI, Y; COSTA, J.B.S.; ABREU, F.A.M. 1984a. Província Tocantins. Setor setentrional. In: ALMEIDA, F.F.A. \& HASUI, Y. eds. $O$ Precambriano no Brasil. São Paulo, Ed. Blücher. p. 137-204.

HASUI, Y; COSTA, J.B.S.; GORAYEB, P.S.S.; LEMOS, R.L.; GAMA, T., Jr.; BEMERGUY, R.L. 1984b. Geologia da região de Paraíso do Norte de Goiás, GO. In: CONGR.BRAS.GEOL., 33. Rio de Janeiro, 1984. Anais... Rio de Janeiro, SBG. v. 5, p. 2220-2233.

HERZ, N.; HASUI, Y; COSTA, J.B.S.; MATTA, M.A.S. 1989. The Araguaia Fold Belt, Brazil: a reactivated Brasíliano-Pan-African cycle (550 Ma) geosuture. Free. Res., 42:371-386.

KOBER, B. 1986. Whole-grain evaporation for ${ }^{207} \mathrm{~Pb} /{ }^{206} \mathrm{~Pb}$-age investigations on single zircons using a double-filament thermal ion source. Contrib. Mineral. Petrol., 93:482-490.

KOBER, B. 1987. Single-grain evaporation combined with $\mathrm{Pb}^{+}$emitter bedding for ${ }^{207} \mathrm{~Pb}{ }^{206} \mathrm{~Pb}$-age investigations using thermal ion mass spec- trometry, and implications to zirconology. Contrib. Mineral. Petrol, 96:63-71.

KRONER, A. \& TODD, W. 1988. Single zircon dating constraining the maximum age of the Barberton greenstone belt, South Africa. $J$. Geoptis. Res., 93:15329-15337.

LAFON JM. MACAMBIRA JB. MACAMBIRA MJB MOURA, C.A.V.; GAUDETTE, H.E.; SOUZA, A.C.C. 1990. A Faixa de Dobramentos Araguaia (TO): novos dados geocronológicos. In: CONGR. BRAS. GEOL., 36. Natal, 1990. Anais... Natal, SBG. v. 5, p. $2550-2563$.

MATTA M.A.S. 1982. Evolução Geológica da Região de Tucurui-PA. Belém. 109 p. (Dissertação de Mestrado, NCGG/UFPa).

MACAMBIRA, J.B. 1983. Geologia e Ocorrências Minerais do Braquianticlinal do Lontra (GO). Bel6m. 108 p. (Dissertação de Mestrado, NCGG/UFPa).

MOURA, C.A.V. 1992. Geochronology and Geochemistry of the Basement Orthogneisses of the Araguaia Belt, Brazil. Durham. 236 p. ( $\mathrm{PhD}$. Thesis, University of New Hampshire).

OLSZEWSKI, W.J.; GAUDETTE, H.E.; CHEATHAM, M. M. 1990. ${ }^{20} \mathrm{~Pb} /{ }^{20} \mathrm{~Pb}$ ages from the chain Lakes Massif, N.W. Maine using single grain direct thermal ionization. In: ANNUAL MEETING NORTHEASTERN SECTION, 25. Syracuse, 1990. Abstracts... Syracuse, GSA. p. 61.

SANTOS, M.; MACAMBIRA, J.B.; KOTSCHOUBEY, B. 1984. Uma proposta para a origem das braquianticlinais de Xambiod e Lontra (GO). Possíveis domos gnáissicos. In: CONGR. BRAS. GEOL., 33. Rio de Janeiro, 1984. Anais... Rio de Janeiro, SBG. v. 7, p. 3400-3414.

SOUZA. A.C.C. 1984. Geologia e Petrologia do Extremo Norte da Serra do Estrondo-GO. Belém. 189 p. (Dissertação de Mestrado, NCGG/UFPa).

SOUZA, A.C.C.; DALL'AGNOL, R.; TEIXEIRA, N.P. 1985. Petrologia do Gnaisse Cantão: implicações na evolução da Faixa de Dobramentos Araguaia, Serra do Estrondo (GO). Rev. Bras. Geoc., 15:300-310.

TEIXEIRA, N.P. 1984. Geologia e Petrologia da Região Central da Serra das Cordilheiras-GO. Belém. 216 p. (Dissertação de Mestrado, NCGG/UFPa).

Manuscrito A772

Recebido em 14 de abril de 1993

Revisao do autor em 18 de maio de 1993

Revisao aceita em 21 de maio de 1993 